\title{
Prevalence of tuberculosis in cattle in the highland regions of Cameroon assessed by the tuberculin skin test
}

J Awahndukum $^{1}$, A C Kudi ${ }^{1,2}$, G Bradley ${ }^{1}$

${ }^{1}$ School of Biomedical and Biological Sciences, University of Plymouth, Plymouth, United Kingdom, ${ }^{2}$ Department of Veterinary Medicine, Faculty of Veterinary Medicince, Zaria, Kaduna State, Nigeria

Email: julius.awahndukum@plymouth.ac.uk

Introduction Tuberculosis (TB) is an important zoonosis caused by bacteria of the Mycobacterium tuberculosis complex. M. bovis is virulent for cattle but can infect humans and cause disease and pathology similar to M. tuberculosis, which is virulent for man (Biet et al. 2005). The epidemiology of bovine TB is largely unknown in Central Africa but its occurrence and implications on livestock production and human health are evident. Politico-economic constraints and lack of attention on zoonotic TB is drastically preventing the "test and slaughter" strategy which has proved very effective in the developed world. The prevalence of human TB in Cameroon is high and increasing rapidly with the spread of the HIV/AID infection. Indications of bovine TB occurrence in Cameroonian livestock are based on post mortem or meat inspection findings. The highlands of Cameroon $\left(3^{\circ} 30^{\prime}-12^{\circ} 30^{\prime} \mathrm{N} \& 8^{\circ}-16^{\circ} \mathrm{E}\right.$ ) including the Western highlands (WHC) bordered to the northeast by the Adamawa Plateau (ADP) contribute over $60 \%$ of the 6 million cattle in Cameroon. Cattle keeping is integral to the socio-economic, cultural and religious activities in these regions. Transhumance, semi-intensive and other traditional systems, where animal graze on sparse vegetations with limited veterinary care, are common and less frequently the intensive system. Herders trek long distances with their herds, sharing grazing and overcrowded night enclosures and watering points usually heavily contaminated with animal and human wastes. These conditions do provide opportunities for the emergence and transmission of bovine TB and no on-station or pre-movement TB tests are carried out on the animals. The aim of this study therefore, was to determine the prevalence of bovine TB based on tuberculin skin test of cattle under various husbandries in the wide geographic and cattle producing highland regions of Cameroon.

Material and methods During the period of March to September 2009, the responses to comparative intradermal tuberculin skin (SICCT) test of 2853 cattle in 7 administrative areas of the WHC and ADP agro-ecological regions of Cameroon were investigated. Intradermal avian $(2500 \mathrm{IU} / \mathrm{ml})$ and bovine $(3000 \mathrm{IU} / \mathrm{ml})$ tuberculin purified protein derivative (PPD) injections $(0.1 \mathrm{ml})$ were used (Kazwala et al. 2001). Cattle keeping communities and owners were identified, listed and subjected to the randomnumber generation method to select cattle herds for the study. Cluster sampling was also used for within herd selection such as preventing recently calved cows (within 2 months post partum) and calves ( $>6$ months) from being tested. The animals used were reared traditionally with or

Table 1 Prevalence of bovine TB by skin test reactors (Percentage, \%; Standard Error, SE)

\begin{tabular}{|c|c|c|c|}
\hline Variable & $\begin{array}{l}\text { No teste } \\
\text { (No } \\
\text { herds) }\end{array}$ & $\begin{array}{l}\text { No of Avian } \\
\text { PPD reactors } \\
(\% ; \mathrm{SE})\end{array}$ & $\begin{array}{l}\text { No of Bovine } \\
\text { PPD reactors } \\
(\% ; \mathrm{SE})\end{array}$ \\
\hline All animals & $2853(84)$ & $82(2.87 ; 0.31)$ & $121(4.24 ; 0.38)$ \\
\hline WHC & $2126(61)$ & $68(3.2 ; 0.38)$ & $104(4.89 ; 0.47)$ \\
\hline ADP & $727(23)$ & $14(1.93 ; 0.51)$ & $17(2.34 ; 0.56)$ \\
\hline $\begin{array}{l}\text { Upgraded } \\
\text { /Exotic }\end{array}$ & 381 & $14(3.67 ; 0.96)$ & $27(7.09 ; 1.31)$ \\
\hline Guadali & 1308 & $20(1.53 ; 0.34)$ & $46(3.52 ; 0.51)$ \\
\hline Namchi & 33 & $0(0 ; 0.00)$ & $1(3.03 ; 2.98)$ \\
\hline Red Bororo & 484 & $33(6.82 ; 1.15)$ & $31(6.4 ; 1.11)$ \\
\hline White Fulani & 647 & $15(2.32 ; 0.59)$ & $16(2.47 ; 0.61)$ \\
\hline Female & 2211 & $67(3.03 ; 0.36)$ & $96(4.34 ; 0.43)$ \\
\hline Male & 642 & $15(2.34 ; 0.60)$ & $25(3.89 ; 0.76)$ \\
\hline Age $\leq 2$ & 613 & $22(3.59 ; 0.75)$ & $17(2.77 ; 0.66)$ \\
\hline $2<$ Age $\leq 4$ & 868 & $26(3 ; 0.58)$ & $32(3.69 ; 0.64)$ \\
\hline $4<$ Age $\leq 6$ & 681 & $18(2.64 ; 0.61)$ & $39(5.73 ; 0.89)$ \\
\hline Age $>6$ & 691 & $16(2.32 ; 0.57)$ & $33(4.78 ; 0.81)$ \\
\hline Extensive & $1725(52)$ & $55(3.19 ; 0.42)$ & $58(3.36 ; 0.43)$ \\
\hline Intensive & $138(4)$ & $2(1.45 ; 1.02)$ & $6(4.35 ; 1.74)$ \\
\hline Semi-intensive & $990(28)$ & $25(2.53 ; 0.50)$ & $57(5.76 ; 0.74)$ \\
\hline Beef herds & 2409 (69) & $74(3.07 ; 0.35)$ & $109(4.52 ; 0.42)$ \\
\hline Dairy herds & $444(15)$ & $8(1.8 ; 0.63)$ & $12(2.7 ; 0.77)$ \\
\hline Herds $\leq 40$ & $1368(57)$ & $34(2.49 ; 0.42)$ & $68(4.97 ; 0.59)$ \\
\hline Herds $>40$ & $1485(27)$ & $48(3.23 ; 0.46)$ & $53(3.57 ; 0.48)$ \\
\hline
\end{tabular}
without transhumance, as well as in semi-intensive and intensive systems. The cattle tested were the indigenious zebus, upgraded and exotic breeds. The purpose of the study was explained to the farmers and animals were tested after an informed consent was given by the owner. The ages and breeds of the animals were provided by the farmers, otherwise determined as described earlier (Blench 1999; Turton 1999). Skin responses to Bovine PPD and Avian PPD individually were also assessed.

Results The prevalence of bovine TB in the highlands of Cameroon based on the responses to the tuberculin skin tests is shown in Table 1. Significantly higher $(\mathrm{P}<0.05)$ skin responses were recorded in the WHC zone, among females and in adult / old ( $\geq 4$ years) cattle reared under the semi-intensive management. There were more skin positive upgraded/exotic cattle $(\mathrm{P}<0.05)$, but positive reactors were spread over the study locations with $57.14 \%(46.56-67.72 \%)$ of the herds infected and particularly $(\mathrm{P}<0.05)$ in the WHC. A strong association (Pearson $\left.\mathrm{X}^{2}=2853 ; P<0.001\right)$ between skin reactions to bovine PPD and avian PPD was noted. Overall, 6.98\% of the animals responded positively to both avian and bovine PPDs while $2.52 \%$ of the animals reacted only to bovine PPD and $1.86 \%$ only to avian PPD.

Conclusion Bovine TB is prevalent in Cameroon and is posing serious risk to public health. Also, many opportunities exist for the emergence of zoonotic TB in the study regions and necessitate further investigation into the modes of transmission and the link between human and bovine TB through molecular techniques.

References Biet F., Boschiroli M.L., Thorel M.F. and Guilloteau L.A. 2005. Vet. Research. 36, 411 - 436.

Blench, R. 1999. Traditional livestock breeds. London, UK; Overseas Development Institute.

Kazwala, RR. Kambarage, DM. Daborn, CJ Nyange, J. Jiwa, SFH and Sharp, JM 2001.Veterinary Research Communications 25, 609-614.

Turton, J. 1999. How to estimate the age of cattle. South Africa: ARC- Onderspoort Veterinary Institute. 